\title{
EXPRESSÃO DIFERENCIAL DE CITOCINAS NOS LADOS DE PRESSÃO E TENSÃO DURANTE A MOVIMENTAÇÃO ORTODÔNTICA
}

Sergio Paulo HILGENBERG; Thiago Pompumaier GARLET; Gustavo Pompumaier GARLET; Emigdio Enrique Orellana JIMENEZ; Ulisses COELHO

Este trabalho se propõe a investigar o padrão expressão de citocinas pró e antiinflamatórias, colágeno tipo I, mediador de remodelação tecidual (MMP-1) e seu inibidor (TIMP-1), fatores osteoclastogênico (RANKL) e osteoblastogênico (CBFA-1), nos diferentes lados sob forças de tensão e pressão, na movimentação ortodôntica. Foram realizados exames quantitativos de reação em cadeia de polimerase (RealTime-PCR), utilizando RNAm proveniente de amostras de ligamento peridontal de dentes submetidos a forças ortodônticas. Foram utilizados dentes que apresentavam indicação ortodôntica de extração, pós-expansão rápida da maxila, e dentes não movimentados como grupo controle, com consentimento informado e declaração de doação dos dentes para pesquisa. Os resultados demonstraram que o lado de pressão apresentou maior expressão de TGF-beta, TNF-a, RANKL e MMP-1, e menor expressão de COL-1 em comparação com o controle, enquanto o lado de tensão apresentou maior expressão de TGF-beta, IL-10, COL-1 e CBFA-1. Comparando os lados de pressão e tensão, observamos maior expressão de IL-10, COL-1 e CBFA-1 no lado de tensão, e maior expressão de TNF-a, RANKL e MMP-1 no lado de pressão. Os resultados obtidos sugerem que o padrão de citocinas determina a natureza da resposta tecidual à força ortodôntica, alterando e guiando o equilíbrio entre reabsorção e neoformação óssea. 